Weronika Kofel

\title{
Problematyka konstrukcyjna nowożytnych retabulów na przykładzie analizy wybranych ołtarzy z kościołów toruńskich
}

\section{Wprowadzenie}

W dotychczasowych badaniach nad ołtarzami w świetle historii sztuki i teologii liturgii, zagadnieniem nierozpoznanym pozostaje problematyka konstrukcyjna drewnianych retabulów. W polskiej literaturze brakuje opracowań, które dążyłyby do systematyzacji wiedzy z zakresu dawnych technik stolarskich stosowanych przy wznoszeniu retabulów i które traktowałyby konstrukcje ołtarzy jako ważny problem badawczy. W wielu opracowaniach dotyczących ołtarzy nowożytnych problematyka konstrukcyjna jest marginalizowana i niedoceniana. Charakterystyczne dla wielu opracowań jest postrzeganie tego rodzaju zabytkowych obiektów przez pryzmat szczególnych cech stylistycznych i kompozycyjnych. Brak pojmowania ołtarzy jako struktury złożonej z różnych części i podzespołów, na którą składają się nie tylko elementy dekoracyjne, takie jak rzeźba i przedstawienia malarskie, ale 
również i detale konstrukcyjne. Również w praktyce konserwatorsko-restauratorskiej drewniana konstrukcja retabulów bardzo często ulega przekształceniom, co ma fundamentalny wpływ na integralność substancji zabytkowej i jej stan zachowania.

Celem artykułu jest zaprezentowanie metody analizy problematyki konstrukcyjnej nowożytnych retabulów oraz podstawowych pojęć konstrukcyjnych ołtarzy na podstawie analizy wybranych obiektów zlokalizowanych w świątyniach torunskich: kościele pw. św. Jakuba Apostoła, kościele pw. Wniebowzięcia Najświętszej Marii Panny oraz katedrze pw. św. Jana Chrzciciela i św. Jana Ewangelisty. Zaprezentowana metoda badań opracowana została na podstawie wniosków wypływających z działalności badawczej poświęconej stolarce architektonicznej i kościelnej prowadzonej przez Zakład Konserwatorstwa Uniwersytetu Mikołaja Kopernika w Toruniu ${ }^{1}$ oraz o wyniki autorskich prac badawczych prowadzonych w $2016 \mathrm{r}$. w ramach projektu poświęconego konstrukcją ołtarzy toruńskich pod patronatem Ministerstwa Kultury i Dziedzictwa Narodowego. W wyniku realizacji projektu opracowana została systematyka rozwiązań konstrukcyjnych nowożytnych ołtarzy oraz propozycja metody badań tego rodzaju zabytkowych konstrukcji².

\section{Metoda badań konstrukcji}

Metoda badań konstrukcji ołtarzy nowożytnych jest procesem trójetapowym, uwzględniającym badania in situ obiektu oraz opracowanie wyników tych badań $\mathrm{w}$ formie rysunkowo-opisowej. Pierwszy etap badań obejmuje inwentaryzacje obiektu, której wynikiem jest opracowanie dokumentacji pomiarowo-rysunkowej. W trakcie inwentaryzacji obiektu należy pamiętać, że warunkiem jej prawidłowego przeprowadzenia jest całkowity dostęp do obiektu. W przypadku konstrukcji retabulum istotna jest dostępność obiektu od strony odwrocia. Dokumentacja pomiarowo-rysunkowa musi być wykonana w skali 1:10 i zawierać następujące rodzaje rysunków: widok frontu retabulum, widok odwrocia, widok boczny oraz przekroje poziome i pionowe. W miarę możliwości wszystkie wskazane rysunki powinny

\footnotetext{
1 Badania nad zagadnieniami konstrukcyjnymi stolarki architektonicznej w Zakładzie Konserwatorstwa zapoczątkował prof. inż. ach. Jan Juliusz Tajchaman. Problematykę konstrukcyjną meblarskiego wyposażenia wnętrz, w tym stolarki kościelnej upowszechnił dr hab. Janusz Krawczyk, prof. UMK. Warto zaznaczyć, że od kilkunastu lat w Zakładzie Konserwatorstwa powstają prace magisterskie poświęcone problematyce konserwatorskiej drewnianych, zabytkowych sprzętów kościelnych np. stall, konfesjonałów, ambon oraz retabulów.

2 Badania konstrukcji nowożytnych retabulów przez autorkę zrealizowano w ramach stypendium z budżetu Ministra Kultury i Dziedzictwa Narodowego. W ramach realizacji projektu opracowany został katalog wybranych ołtarzy toruńskich oraz studium poświęcone konstrukcji nastaw: KOFEL 2016 a; KOFEL 2016 b.
} 
znaleźć się na jednym arkuszu papieru. Ważne jest, aby rysunki zostały rozmieszczone w następującym porządku. Idąc od lewej strony, w pierwszej kolejności umieszczony powinien zostać rysunek odwrocia, następnie widok boczny i widok lica retabulum. Przekroje poziome retabulum należy umieścić bezpośrednio pod widokiem frontalnym, natomiast przekrój pionowy obok wskazanego widoku. Każdy rysunek powinien zawierać tabelkę opisową oraz podziałkę graficzną. Przy wykonywaniu rysunków widoków i przekrojów ważne jest, aby oprócz samej drewnianej struktury retabulum, uwzględnić na nich również formę m.in. stipesu, antepedium, stopni poprzedzających stół ołtarzowy czy też ukazać to, co występuje za odwrociem retabulum np. masyw muru, półfilaru czy filaru. Ukazanie retabulum na tle wskazanych elementów jest istotne dla określenia konstrukcji podstawowej obiektu, wynikającej z relacji drewnianej struktury z mensą i stipsem oraz jej powiązania z architekturą. Ilość przekrojów pionowych i poziomych konstrukcji musi być dostosowana do stopnia złożoności drewnianej struktury. Czasem istnieje konieczność wykonania kilku tego typu przekrojów. Linie przekrojowe powinny natomiast przebiegać w miejscach, które pozwalają na pokazanie jak największej ilości danych rozwiązań konstrukcyjnych i ich różnorodności.

Kolejny etap opracowywania wyników badań polega na wykonaniu rysunków $\mathrm{w}$ aksonometrii rozłożonej. Rysunki tego rodzaju w przypadku konstrukcji retabulów pozwalają na bardziej dokładne zaprezentowanie problematyki konstrukcyjnej. Dokumentacja pomiarowo-rysunkowa ze względu na swój charakter uniemożliwia pokazanie szczegółowych rozwiązań konstrukcyjnych, w szczególności danych połączeń i złącz stolarskich. Rysunki w aksonometrii powinny być rysunkami poglądowymi, wykonywanymi bez użycia skali, ale z zachowaniem proporcji danych elementów konstrukcji. Zaleca się, aby szczegółowość tego rodzaju rysunków zależna była od złożoności problematyki konstrukcyjnej. Rozrysowanie konstrukcji retabulum w aksonometrii rozłożonej powinno skupiać się przede wszystkim na wizualizacji: podstawowych założeń konstrukcyjnych, podziale na dane moduły konstrukcyjne i ich budowie szczegółowej. Rysunek tego typu powinien również zostać umieszczony na jednym podkładzie rysunkowym i zawierać odpowiednią tabelę opisową.

Ostatni etap badań konstrukcji stanowi opis analizowanego obiektu. Opis konstrukcji retabulum podobnie jak metoda, jest również procesem trójetapowym. Podział opisu konstrukcji na trzy części, umożliwia opracowanie uporządkowanej charakterystyki konstrukcji według zasady „od ogółu do szczegółu”. W każdym z wyróżnionych etapów konstrukcja omawiana jest $\mathrm{z}$ różnym stopniem szczegółowości. W pierwszej kolejności należy określić podstawowe założenia 
konstrukcyjne obiektu, wskazać podstawowy typ konstrukcyjny ołtarza, określić rodzaj układu konstrukcyjnego obiektu, ilość i rodzaj modułów konstrukcyjnych. Drugim etapem opisu jest przejście do szczegółowego omówienia konstrukcji danego modułu, w którym charakteryzuje się: rodzaj konstrukcji przestrzennych bądź płaszczyznowych oraz dookreśla się ilość i formę danych elementów podzespołu konstrukcyjnego. W ostatnim etapie opisu identyfikuje się rodzaje połączeń i złącz stolarskich.

Bardzo ważnym elementem badań konstrukcji jest również wykonanie dokumentacji fotograficznej. Fotografie powinny zawierać ujęcia całego obiektu ze wszystkich stron oraz jego charakterystycznych fragmentów. W miarę możliwości na fotografiach powinny zostać zaprezentowane dane węzły konstrukcyjne, rodzaje złącz stolarskich oraz sposób opracowania powierzchni elementów drewnianych. Fotografie powinny również dokumentować stan zachowania obiektu.

\section{Podstawowe zagadnienia z zakresu konstrukcji ołtarzy nowożytnych}

Analiza relacji zachodzących pomiędzy drewnianą strukturą, a stipesem i mensą, pozwala na wyodrębnienie wśród nowożytnych ołtarzy dwóch podstawowych rodzajów konstrukcji: ołtarzy $\mathrm{z}$ retabulum oraz ołtarzy $\mathrm{z}$ drewnianą strukturą $\mathrm{w}$ formie baldachimu/cyborium. W przypadku pierwszego rozwiązania, drewna konstrukcja zostaje posadowiona na mensie i stipesie lub zostaje ustawiona za stołem ołtarzowym. W obu tych przypadkach drewniana konstrukcja retabulum oraz stipes i mensa są ze sobą połączone. Natomiast $\mathrm{w}$ drugim typie konstrukcyjnym, drewniana konstrukcja jest strukturą niezwiązaną bezpośrednio z stipesem i mensą.

Złożona problematyka konstrukcyjna w szczególności jest charakterystyczna dla ołtarzy $\mathrm{z}$ retabulum. W ich przypadku kluczowa staję się identyfikacja relacji zachodzących pomiędzy stipesem wraz z mensą a drewnianą strukturą oraz analiza rozkładu sił i punktów podparcia drewnianej konstrukcji. Tego rodzaju zależności konstrukcyjne wpłynęły na wydzielenie wśród retabulów nowożytnych trzech podstawowych typów konstrukcyjnych: retabulów o konstrukcji w typie S, w typie SP oraz S+ (tab.1). W retabulach o konstrukcji w typie S, ciężar drewnianej struktury spoczywa wyłącznie na mensie i stipesie. Mensa i stipes w przypadku wskazanego rozwiązania stanowią podstawowy punkt podparcia drewnianej konstrukcji. Struktura tego typu retabulum tworzy pod względem konstrukcyjnym jak i kompozycyjnym addycyjną część, niezwiązaną na sposób stolarski z mensą i stipesem. W przypadku retabulów w typie SP, ciężar drewnianej struktury spoczywa na mensie i stipesie oraz posadzce. W tego rodzaju rozwiązaniach struktura retabulum przybiera na tyle 
rozbudowaną formę, że „obrasta” mense i stipes, nie tworząc tym samym addycyjnej formy. W retabulach o konstrukcji w tym typie, ciężar drewnianej struktury posiada dwa punkty podparcia- stipes i mense oraz posadzkę. Trzeci rodzaj konstrukcji retabulów jest modyfikacją wcześniej wyróżnionych typów. Retabulum o konstrukcji $\mathrm{S}+$, pod względem kompozycyjnym odpowiada rozwiązaniom konstrukcji w typie SP (w których ciężar drewnianej struktury spoczywa na mesnie, stipesie i posadzce), ale pod względem konstrukcyjnym jest odmianą konstrukcji w typie S. W przypadku tego rodzaju rozwiązania, drewniana struktura retabulum posiada jeden punkt podparcia (stipes i mense), pomimo umieszczonych po bokach stipesu, na posadzce drewnianych konstrukcji, które nie spełniają żadnych funkcji nośnych.

\section{KONSTRUKCJA OŁTARZY NOWOŻYTNYCH}

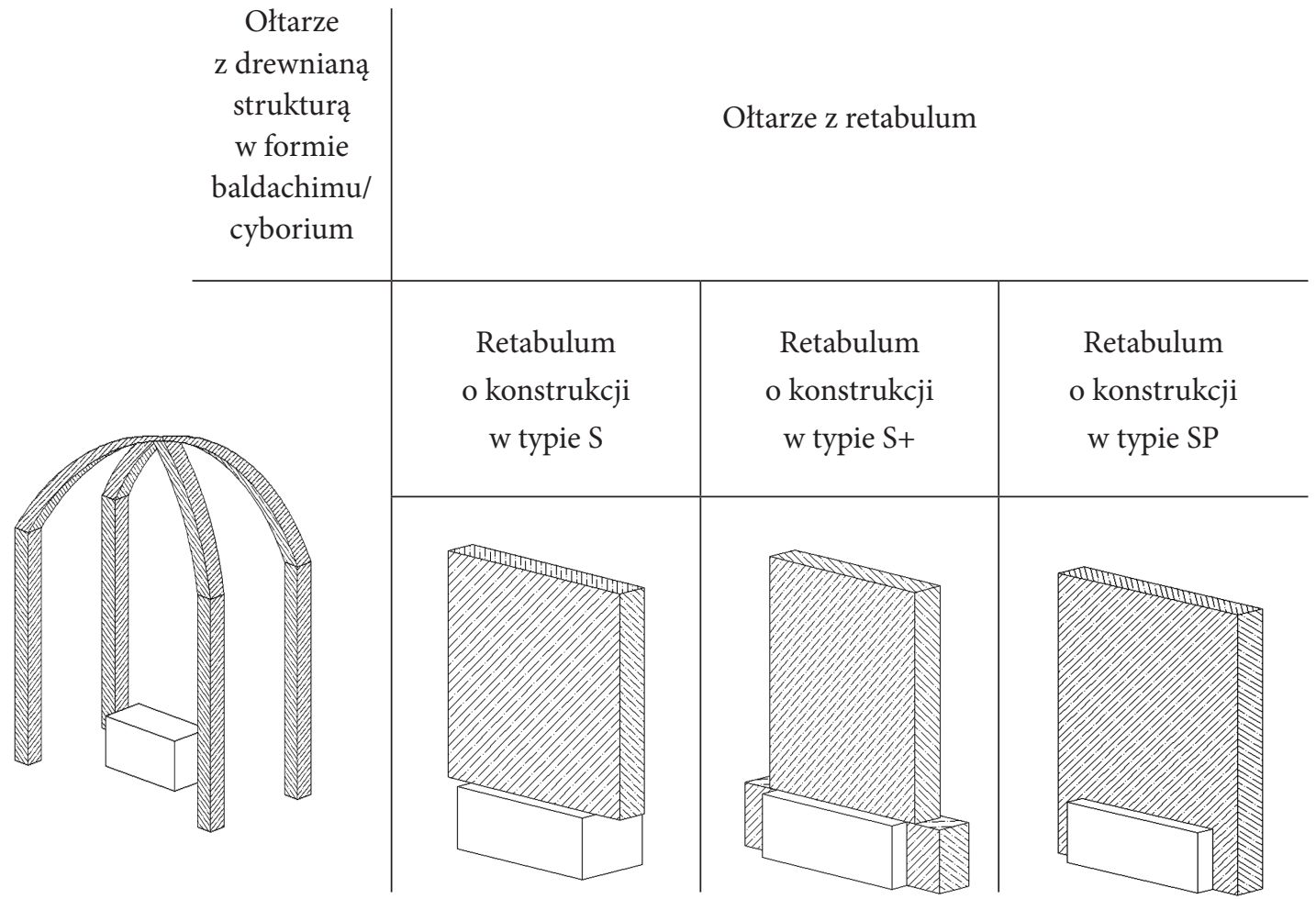

Tabela 1. Typologia konstrukcji

ołtarzy nowożytnych, oprac Weronika Kofel 
Ze względu na sposób przenoszenia ciężaru struktury własnej retabulum i jej powiązania $\mathrm{z}$ architekturą, można dodatkowo podzielić wskazane rozwiązania konstrukcyjne na konstrukcje: nośne, samonośne oraz pozornie samonośne. Przez konstrukcje nośną należy rozumieć taki typ konstrukcji, w której retabulum ołtarzowe spełniało funkcję ściany, za którą występował podział przestrzeni na dwie kondygnacje. $\mathrm{W}$ takim przypadku drewniana konstrukcja retabulum przenosiła częściowo ciężar stropu chóru konwentualnego. Tego typu rozwiązania znane są z terenu Torunia na przykładzie pierwotnej konstrukcji ołtarza głównego z kościoła pw. św. Piotra i Pawła za czasów franciszkanów-reformatów oraz z kościoła pw. św. Jakuba Apostoła, znajdującego się pod opieką sióstr benedyktynek. W konstrukcji samonośnej retabulum ciężar własny drewnianej konstrukcji przenoszony jest w całości na dane podpory (stipes wraz z mensą oraz posadzkę). Natomiast konstrukcja samonośna pozorna jest takim rozwiązaniem, w którym ciężar własny drewnianej konstrukcji retabulum przenoszony jest zarówno na podpory (posadzkę, stipes), ale również na filary, półfilary czy ściany, poprzez powiązanie układu elementów konstrukcyjnych $\mathrm{z}$ architekturą przy pomocy systemu odciągów drewnianych bądź metalowych.

Każdy z wskazanych z typów konstrukcyjnych retabulum charakteryzuje się zróżnicowanym układem konstrukcyjnym oraz budową szczegółową. Podstawową jednostką konstrukcyjną retabulów są moduły konstrukcyjne. Przez moduł należy rozumieć zespół i podzespoły konstrukcyjne, tworzące pojedyncze segmenty modułowe, które tworzą jednopoziomową lub wielopoziomową strukturę konstrukcyjną, odpowiadającą wydzielonym w podziale kompozycyjnym kondygnacjom danego retabulum. Retabula nowożytne były wznoszone jako konstrukcje jednopoziomowe lub wielopoziomowe, a ilość i rodzaj danych modułów na wyróżnionym poziomie była dowolna. Wśród ołtarzy możemy spotkać retabula o układzie konstrukcyjnym jednopoziomowym-jednomodułowym, jednopoziomowym-pięciomodułowym lub też dwupoziomowym z pierwszym poziomem dwumodułowym, drugim-jednomodułowym.

Rozpoznanie problematyki konstrukcyjnej ołtarzy pozwala dostrzec pewną zależność w ich budowie. Do każdego z typów konstrukcyjnych retabulów przynależny jest określony rodzaj modułu konstrukcyjnego. Retabula o konstrukcji $\mathrm{w}$ typie S oraz S+ wznoszone były z wykorzystaniem modułu złożonego. Moduł tego rodzaju odznacza się tym, że wchodzące w jego skład zespoły i podzespoły konstrukcyjne tworzą dwa układy konstrukcyjne przestrzenne, zamykające od góry i dołu układ płaszczyznowy. Połączenie tych układów następuje przy 
pomocy odpowiedniego złącza stolarskiego i tzw. elementu dwufunkcyjnego, który stanowi integralną część zarówno układu konstrukcyjnego przestrzennego jak i płaszczyznowego. Dla modułu złożonego charakterystyczne jest również występowanie w danym układzie konstrukcyjnym ściśle określonych, szczegółowych rozwiązań konstrukcyjnych. Na podstawie przeprowadzonych badań wyraźnie widać, że układy konstrukcyjne przestrzenne zbudowane są w oparciu o założenia konstrukcji wieloskrzyniowej. Natomiast układy konstrukcyjne płaszczyznowe wykonywano w konstrukcji ramowej lub ramowo-płycinowej. W retabulach o konstrukcji w typie S+ oprócz modułu złożonego, występują również moduły proste. Moduły proste złożone są z jednego rodzaju układów elementów konstrukcyjnych: przestrzennych lub płaszczyznowych. Układy przestrzenne w tego rodzaju module tworzą zazwyczaj konstrukcje skrzyniowe oraz wieloskrzyniowe. Układy płaszczyznowe wznoszone są w konstrukcji ramowej, ramowo-płycinowej lub deskowej. Moduł prosty występuję również w retabulach o konstrukcji SP, gdzie odpowiada wydzielonemu w kompozycji dolnemu poziomowi strefy cokołowej. W przypadku retabulów o konstrukcji w typie S, moduł prosty występuję najczęściej w dolnej części układu konstrukcyjnego. Moduł tego rodzaju w przypadku retabulów o kilku poziomowych układach konstrukcyjnych, zlokalizowany jest zazwyczaj najwyżej tworząc odrębną kondygnację lub zwieńczenie ołtarza. Struktura retabulów w typie SP w znacznej części zbudowana jest przy użyciu modułu mieszanego. Moduł mieszany tworzą najczęściej dwa układy konstrukcyjne przestrzenne i płaszczyznowe, które są zestawione ze sobą i połączone przy pomocy drewnianych kołków. Układy przestrzenne w tego typu strukturze wznoszone są zazwyczaj z wykorzystaniem konstrukcji skrzyniowej, natomiast układy konstrukcyjne płaszczyznowe, konstrukcji ramowej lub ramowo-płycinowej. Moduł mieszany w retabulach o konstrukcji w typie SP, występuje odrębnie dla każdej z wyróżnionej w podziale kompozycyjnym stref (strefy cokołowej, środkowej i belkowania). Wyróżnione trzy rodzaje modułów: moduły proste, moduły złożone oraz moduły mieszane są jednocześnie pod względem konstrukcyjnym samodzielnym segmentem modułowym, tzn. że tworzą dany układ konstrukcyjny poprzez swobodne nastawienie na styk jednego modułu na drugi. W konstrukcjach retabulów nowożytnych występują również struktury, które nie tworzą samodzielnego segmentu modułowego, ponieważ zostają połączone przy pomocy złącz stolarskich z innymi modułami tworzącymi konstrukcje retabulum. Moduły tego rodzaju nazywane są modułami łączonymi i występują w trzech podstawowym rodzajach jako: moduły proste łączone, moduły złożone łączone oraz moduły mieszane łączone. 
OŁTARZE TORUŃSKIE Z XVII i XVIII w.

\begin{tabular}{|c|c|}
\hline Wezwanie i lokalizacja ołtarza & Data powstania \\
\hline $\begin{array}{l}\text { Ołtarz pw. Zaśnięcia NMP, katedra pw. św. Jana } \\
\text { Chrzciciela i św. Jana Ewangelisty }\end{array}$ & $\begin{array}{l}1610-1620 \mathrm{r} . \\
\text { lub } 1620-1630 \mathrm{r}\end{array}$ \\
\hline $\begin{array}{l}\text { Ołtarz pw. Świętego Krzyża, katedra pw. św. Jana } \\
\text { Chrzciciela i św. Jana Ewangelisty }\end{array}$ & ok. 1653 r. \\
\hline $\begin{array}{l}\text { Ołtarz pw. Niepokalanego Poczęcia NMP, } \\
\text { katedra pw. św. Jana Chrzciciela } \\
\text { i św. Jana Ewangelisty }\end{array}$ & $1690 \mathrm{r}$. \\
\hline $\begin{array}{l}\text { Ołtarz pw. św. Anny, katedra pw. św. Jana } \\
\text { Chrzciciela i św. Jana Ewangelisty }\end{array}$ & pocz. XVIII w. \\
\hline $\begin{array}{l}\text { Ołtarz pw. Anioła Stroża, katedra pw. św. Jana } \\
\text { Chrzciciela i św. Jana Ewangelisty }\end{array}$ & pocz. XVIII w. \\
\hline $\begin{array}{l}\text { Ołtarz pw. św. Barbary, katedra pw. św. Jana } \\
\text { Chrzciciela i św. Jana Ewangelisty }\end{array}$ & ok.1720-1725 r. \\
\hline $\begin{array}{l}\text { Ołtarz pw. Matki Boskiej Ostrobramskiej, } \\
\text { kościół pw. św. Jakuba Apostoła }\end{array}$ & ok. $1690-1700$ r. \\
\hline $\begin{array}{l}\text { Ołtarz pw. św. Barbary, kościół } \\
\text { pw. św. Jakuba Apostoła. }\end{array}$ & przełom XVII i XVIII w. \\
\hline $\begin{array}{l}\text { Ołtarz pw. św. Piotra, kościół pw. św. Jakuba } \\
\text { Apostoła. }\end{array}$ & po $1667 \mathrm{r}$. \\
\hline $\begin{array}{l}\text { Ołtarz pw. Serca Jezusowego, kościół } \\
\text { pw. św. Jakuba Apostoła. }\end{array}$ & przełom XVII i XVIII w. \\
\hline $\begin{array}{l}\text { Ołtarz pw. św. Józefa, kościół } \\
\text { pw. św. Jakuba Apostoła. }\end{array}$ & ok. $1760-1780$ r. \\
\hline $\begin{array}{l}\text { Ołtarz pw. św. Anny, kościół } \\
\text { pw. Wniebowzięcia NMP }\end{array}$ & $1725-1730 \mathrm{r}$. \\
\hline
\end{tabular}

Tabela. 2. Wykaz szczegółowy retabulów toruńskich poddanych badaniom konstrukcyjnym, oprac Weronika Kofel 


\section{Problematyka konstrukcyjna} ołtarzy toruńskich. Stan badań

Zainteresowanie toruńską stolarką kościelną okresu nowożytnego pojawiło się już w XIX wieku. Pierwsze informacje na temat nowożytnych dzieł stolarskich i snycerskich odnaleźć można w publikacjach poświęconych historii miasta i znajdujących się na jego terenie obiektach sakralnych ${ }^{3}$. Jednakże umieszczone w nich informacje dotyczące ołtarzy są bardzo ogólne. Najczęściej odnotowywano w nich lokalizację tego typu obiektów, określano czas powstania i umieszczano krótki opis formalny. Tendencja ta utrzymywała się, aż do lat $60 \mathrm{XX}$ wieku.

Przełomem w badaniach nad snycerką toruńską był wydany w 1965 roku. na łamach Teki Komisji Historii Sztuki, artykuł poświęcony snycerce toruńskiej, autorstwa Bogny Jakubowskiej ${ }^{4}$. Autorka omówiła w nim dzieła snycerskie z okresu XVIII wieku, w większości związane z dekoracją ołtarzy. W opracowaniu szczegółowo przeanalizowała wpływ uwarunkowań społeczno-religijnych na wzmożony ruch fundacji wyposażenia do świątyń toruńskich w osiemnastym stuleciu. Drobiazgowo przedstawiła formy powstałych ołtarzy, ich kompozycję i dekorację. Praca Jakubowskiej była pierwszym tego typu opracowaniem, które wyznaczało początek analitycznego zainteresowania snycerką toruńską okresu nowożytnego

Nurt wyznaczony przez Jakubowską kontynuowała Jolanta Goławska, która w 1968 roku. wydała artykuł poświęcony problematyce barokowej snycerki toruńskiej5. Goławska podobnie jak jej poprzedniczka, przedstawiła szczegółowo kontekst społeczno-religijny towarzyszący powstaniu obiektów oraz omówiła przykłady dzieł snycerskich okresu baroku, analizując przede wszystkim dekorację ołtarzy. $\mathrm{Na}$ podstawie analizy obiektów wyróżniła repertuar form i motywów dekoracyjnych charakterystyczny dla snycerki toruńskiej okresu XVII i XVIII wieku. W artykule ponadto zamieściła, krótkie opisy ołtarzy, w których po raz pierwszy pojawiło się zagadnienie konstrukcji. Jednakże pojęcie konstrukcji przez autorkę stosowane było niewłaściwie. Goławska pisząc o konstrukcji ołtarza, opisywała właściwie dyspozycję kompozycyjną, a nie układ drewnianej struktury wraz połączeniami.

Ważnym etapem $\mathrm{w}$ rozpoznaniu problematyki ołtarzy toruńskich i snycerki były powstające od końca lat 90. XX wieku. opracowania monograficzne poświęcone historii kościołów toruńskich i ich wyposażeniu' ${ }^{6}$ Powstanie tego typu publikacji zapoczątkował artykuł Jerzego Domasłowskiego poświecony dziejom kościoła pw. św. Ducha, opublikowany na łamach Rocznika Toruńskiego w 1992 roku

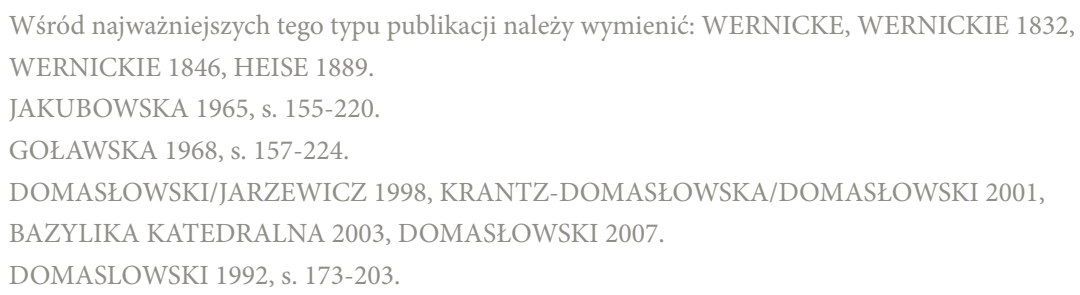


W wydawanych publikacjach znalazły się rozbudowane opisy retabulów, identyfikacja pracujących przy ich budowie warsztatów i artystów, próba uporządkowania danych rozwiązań stylistycznych i kompozycyjnych. W monografiach powtórzono główne ustalenia dotyczące snycerki autorstwa B. Jakubowskiej i J. Goławskiej. Uaktualnieniu uległy jedynie informację związane z ołtarzami z kościoła pw. św. Jakuba, a dokładnie wyodrębnieniu grupy ołtarzy wtórnych, przeniesionych do świątyni w 1831 roku z kościoła podominikańskiego pw. św. Mikołaja.

Po raz pierwszy problematyka konstrukcyjna ołtarzy toruńskich została podjęta w 2006 roku przez Piotra Trybuszewskiego na łamach Rocznika Muzeum Okręgowego w Toruniu ${ }^{8}$. Autor artykułu dokonał szczegółowej analizy konstrukcji ołtarza głównego z kościoła pw. św. Jakuba Apostoła, na podstawie dokumentacji pomiarowo-rysunkowej i badań konstrukcyjnych obiektu. Problematyka konstrukcyjna tegoż ołtarza została również podjęta przez autora kilka lat później, w publikacji poświęconej problematyce konserwatorskiej zabytkowej stolarki we wnętrzach sakralnych ${ }^{9}$. W artykule oprócz omówienia konstrukcji ołtarza, zakresu podjętych przy nim prac konserwatorsko-restauratorskich, zwrócono uwagę, na potrzebę badań konstrukcji ołtarzowych i znaczenia tego rodzaju zagadnień dla analiz z zakresu problematyki konserwatorskiej zabytkowych ołtarzy.

Wzbogacenie problematyki badawczej ołtarzy toruńskich o zagadnienia związane z ich konstrukcją dokonało się za sprawą sesji naukowych poświęconych historii kościołów toruńskich, organizowanych od 2002 roku przez Toruński Oddział Stowarzyszenia Historyków Sztuki przy współpracy z Instytutem Zabytkoznawstwa i Konserwatorstwa Uniwersytetu Mikołaja Kopernika w Toruniu ${ }^{10}$. Problematyka konstrukcyjna ołtarzy w ramach jednej z sesji na przykładzie ołtarza głównego z kościoła pw. św. Apostołów Piotra i Pawła poruszona została przez Petera Machale ${ }^{11}$. W publikacjach pokonferencyjnych znalazły się również artykuły poświęcone problematyce nowożytnego wyposażenia wnętrz toruńskich kościołów, w tym również ołtarzy. W artykułach zaprezentowano głównie kwestie związane z zagadnieniami kompozycyjnymi i stylistycznymi ołtarzy, w szczególności walorami ich dekoracji malarskiej i rzeźbiarskiej ${ }^{12}$.

W powstających późniejszych pracach dotyczących toruńskiej snycerski nowożytnej, poruszone zostają przede wszystkim zagadnienia stylistyczne. W 2009 roku wydana została monumentalna synteza poświęcona dziejom toruńskiej sztuki, 
której powstanie wiązało się z obchodzoną w 2008 roku 775 rocznicą lokacji miasta ${ }^{13}$. W części pracy poświeconej dziejom sztuki nowożytnej, opracowanej przez Katarzynę Kluczwajd i Jacka Tylickiego, znalazły się informację poświęcone zagadnieniom historyczno-stylistycznym ołtarzy toruńskich, jednakże nie wykorzystano w niej wyników badań Piotra Trybuszewskiego czy Petera Machali.

Najnowszym opracowaniem dotyczącym zagadnień nowożytnej snycerski Torunia jest praca doktorska poświęcona toruńskiemu cechowi rzeźbiarskiemu i snycerce toruńskiej z okresu XVII i XVIII autorstwa Bartłomieja Łyczaka ${ }^{14}$.

Podsumowując należy zauważyć, że zagadnienie ołtarzy toruńskich okresu nowożytnego pojawia się najczęściej na przedłużeniu rozważań dotyczących dziejów snycerki Torunia. W literaturze podejmującej tego rodzaju problematykę można dostrzec, że ołtarze nie są postrzegane jako struktura złożona z elementów dekoracyjnych i podzespołów konstrukcyjnych. W wielu opracowaniach omawiane są zagadnienia związane z formą dekoracji, układem kompozycyjnym ołtarzy i stosowaniem w nich podziałów oraz elementów wywodzących się z architektury. Wielu autorów opisuje również zależność pomiędzy budową ołtarzy oraz innych elementów wyposażenia wnętrz sakralnych, a aktualną sytuacją wyznaniową i społeczną miasta. W stanie badań poświęconym ołtarzom toruńskim brakuje pogłębionej refleksji nad zagadnieniami związanymi z ich budową. Analiz, które kontynuowałyby podjętą problematykę konstrukcyjną oraz dążyłyby do systematyki danych rozwiązań i klasyfikacji układów konstrukcyjnych.

\section{Konstrulkcja wybranych retabulów toruńskich}

W kontekście badań nad konstrukcją retabulów wybór ołtarzy zlokalizowanych w kościołach toruńskich nie jest przypadkowy. Ołtarze toruńskie okresu nowożytnego odznaczają się dużą różnorodnością stylistyczną i kompozycyjną. Wartość ta miała zasadniczy wpływ na ostateczne wytypowanie obiektów do bezpośrednich badań konstrukcyjnych, aby na ich podstawie przeanalizować, na ile różnorodność formy jest powiązana z wielorakością rozwiązań konstrukcyjnych. Ołtarze z XVII i XVIII w. z toruńskich świątyń były budowane z wykorzystaniem różnych założeń konstrukcyjnych. Wśród nich można odnaleźć dwa podstawowe typy konstrukcyjne takie jak: jak ołtarze $\mathrm{z}$ drewnianą strukturą $\mathrm{w}$ formie baldachimu oraz ołtarze z drewnianym retabulum. Przeprowadzone badania pozwalają zauważyć, że zróżnicowanie rozwiązań konstrukcyjnych jest znamienne dla ołtarzy z retabulum, a ich różnorodność opiera się na wykorzystaniu do ich budowy różnych rodzajów modułów konstrukcyjnych (tabela 3). 
Konstrulkcja nowożytnych retabulów toruńskich z XVII i XVIII w.

\begin{tabular}{|c|c|c|c|c|c|c|}
\hline \multirow[t]{2}{*}{ Wezwanie i lokalizacja ołtarza } & \multirow{2}{*}{$\begin{array}{l}\text { Typ } \\
\text { retabulum }\end{array}$} & \multirow{2}{*}{$\begin{array}{c}\text { Ilość } \\
\text { modułów } \\
\text { konstrukcyj- } \\
\text { nych }\end{array}$} & \multicolumn{4}{|c|}{ Rodzaj modułu konstrukcyjnego } \\
\hline & & & $\begin{array}{l}\text { Moduł } \\
\text { prosty }\end{array}$ & $\begin{array}{l}\text { Moduł } \\
\text { złożony }\end{array}$ & $\begin{array}{l}\text { Moduł } \\
\text { mieszany }\end{array}$ & $\begin{array}{l}\text { Moduł } \\
\text { łączony }\end{array}$ \\
\hline $\begin{array}{l}\text { Ołtarz pw. Zaśnięcia } \\
\text { NMP, katedra pw. św. } \\
\text { Jana Chrzciciela i św. Jana } \\
\text { Ewangelisty }\end{array}$ & $S$ & 1 & & $\mathrm{X}$ & & \\
\hline $\begin{array}{l}\text { Ołtarz pw. Świętego } \\
\text { Krzyża, katedra pw. św. } \\
\text { Jana Chrzciciela i św. Jana } \\
\text { Ewangelisty }\end{array}$ & S & 2 & & $2 \mathrm{X}$ & & \\
\hline $\begin{array}{l}\text { Ołtarz pw. Niepokalanego } \\
\text { Poczęcia NMP, katedra } \\
\text { pw. św. Jana Chrzciciela } \\
\text { i św. Jana Ewangelisty }\end{array}$ & $S$ & 3 & $\mathrm{X}$ & $2 \mathrm{X}$ & & \\
\hline $\begin{array}{l}\text { Ołtarz pw. św. Anny, katedra } \\
\text { pw. św. Jana Chrzciciela } \\
\text { i św. Jana Ewangelisty }\end{array}$ & $S$ & 1 & & $\mathrm{X}$ & & \\
\hline $\begin{array}{l}\text { Ołtarz pw. Anioła Stroża, } \\
\text { katedra pw. św. Jana Chrzciciela } \\
\text { i św. Jana Ewangelisty }\end{array}$ & $S$ & 1 & & $\mathrm{X}$ & & \\
\hline $\begin{array}{l}\text { Ołtarz pw. św. Barbary, } \\
\text { katedra pw. św. Jana Chrzciciela } \\
\text { i św. Jana Ewangelisty }\end{array}$ & $S$ & 2 & & $2 \mathrm{X}$ & & \\
\hline $\begin{array}{l}\text { Ołtarz pw. Matki Boskiej } \\
\text { Ostrobramskiej, kościół } \\
\text { pw. św. Jakuba Apostoła }\end{array}$ & S & 1 & & $\mathrm{X}$ & & \\
\hline $\begin{array}{l}\text { Ołtarz pw. św. Barbary, kościół } \\
\text { pw. św. Jakuba Apostoła. }\end{array}$ & $S$ & 1 & & $\mathrm{X}$ & & \\
\hline $\begin{array}{l}\text { Ołtarz pw. św. Piotra, kościół } \\
\text { pw. św. Jakuba Apostoła. }\end{array}$ & S+ & 3 & $2 \mathrm{X}$ & $\mathrm{X}$ & & \\
\hline $\begin{array}{l}\text { Ołtarz pw. Serca Jezusowego, } \\
\text { kościół pw. św. Jakuba } \\
\text { Apostoła. }\end{array}$ & $\mathrm{S}+$ & 3 & $2 \mathrm{X}$ & $\mathrm{X}$ & & \\
\hline $\begin{array}{l}\text { Ołtarz pw. św. Józefa, kościół } \\
\text { pw. św. Jakuba Apostoła. }\end{array}$ & SP & 5 & $3 \mathrm{X}$ & & $2 \mathrm{X}$ & $3 X$ \\
\hline $\begin{array}{l}\text { Ołtarz pw. św. Anny, kościół } \\
\text { pw. Wniebowzięcia NMP }\end{array}$ & SP & 5 & $3 \mathrm{X}$ & & $2 \mathrm{X}$ & \\
\hline
\end{tabular}

Tabela 3. Konstrukcja nowożytnych ołtarzy toruńskich z XVII i XVIII w.

Wykaz ołtarzy z retabulum o konstrukcji S, S+ i SP oraz budowy modułowej, oprac Weronika Kofel 
Szczegółowa problematyka konstrukcyjna retabulów zostanie przedstawiona na podstawie analizy dwóch obiektów toruńskich: ołtarza pw. św. Józefa z kościoła pw. św. Jakuba Apostoła oraz ołtarza pw. Niepokalanego Poczęcia $\mathrm{NMP}^{15} \mathrm{z}$ katedry pw. św. Jana Chrzciciela i św. Jana Ewangelisty w Toruniu. Oba ołtarze reprezentują nie tylko różnorodne rozwiązania stylistyczne, ale również konstrukcyjne-retabulum w typie S i SP.

kościół pw. św. Jakuba Apostoła. Retabulum ołtarza pw. św. Józefa. Widok ogólny od strony frontu, fot. Weronika Kofel, 2016

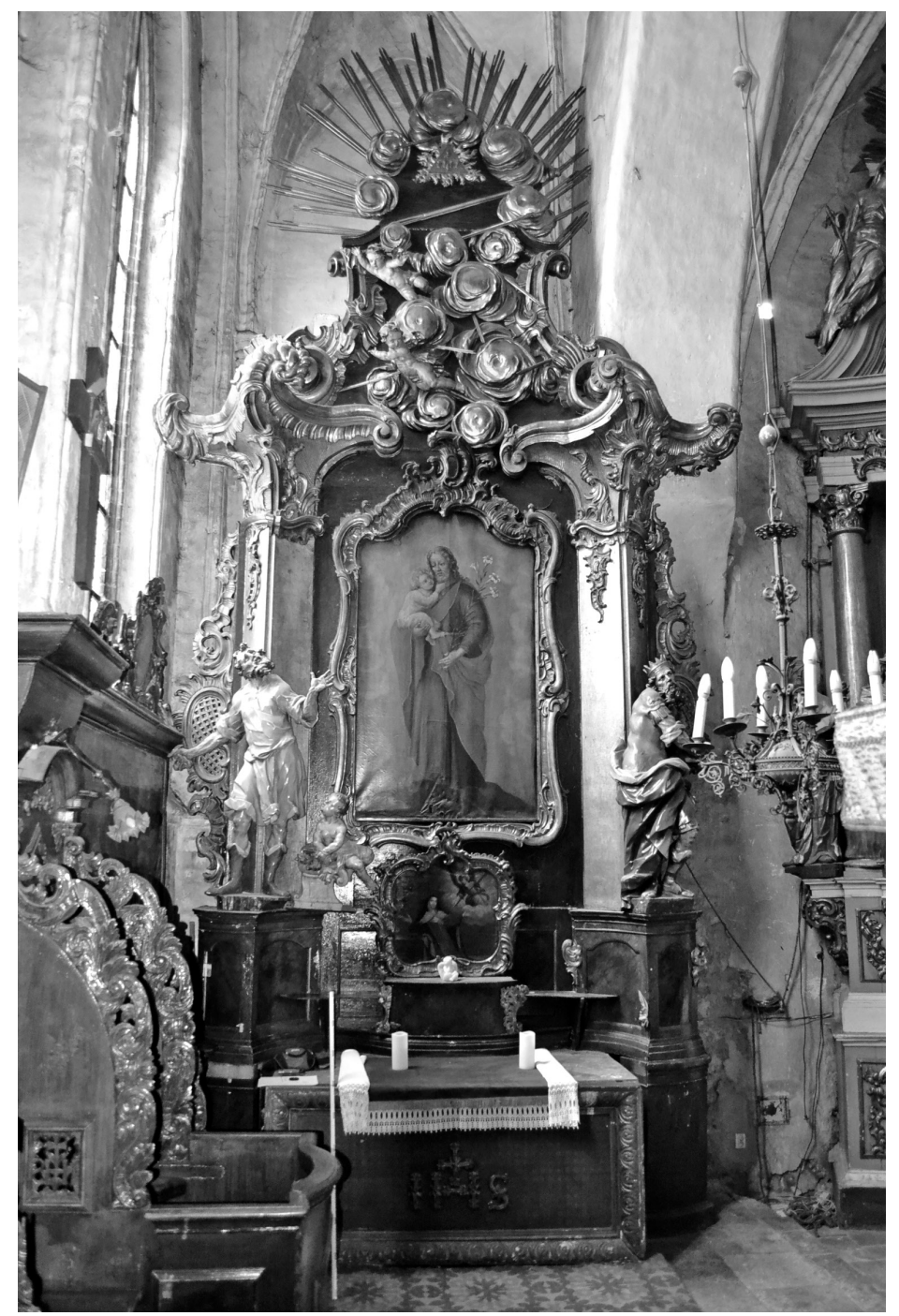

15 Więcej o historii ołtarza oraz zakresie prac konserwatorsko-restauratorskich w: SZMIT-NAUD 1996, SZMIT-NAUD 2010. 


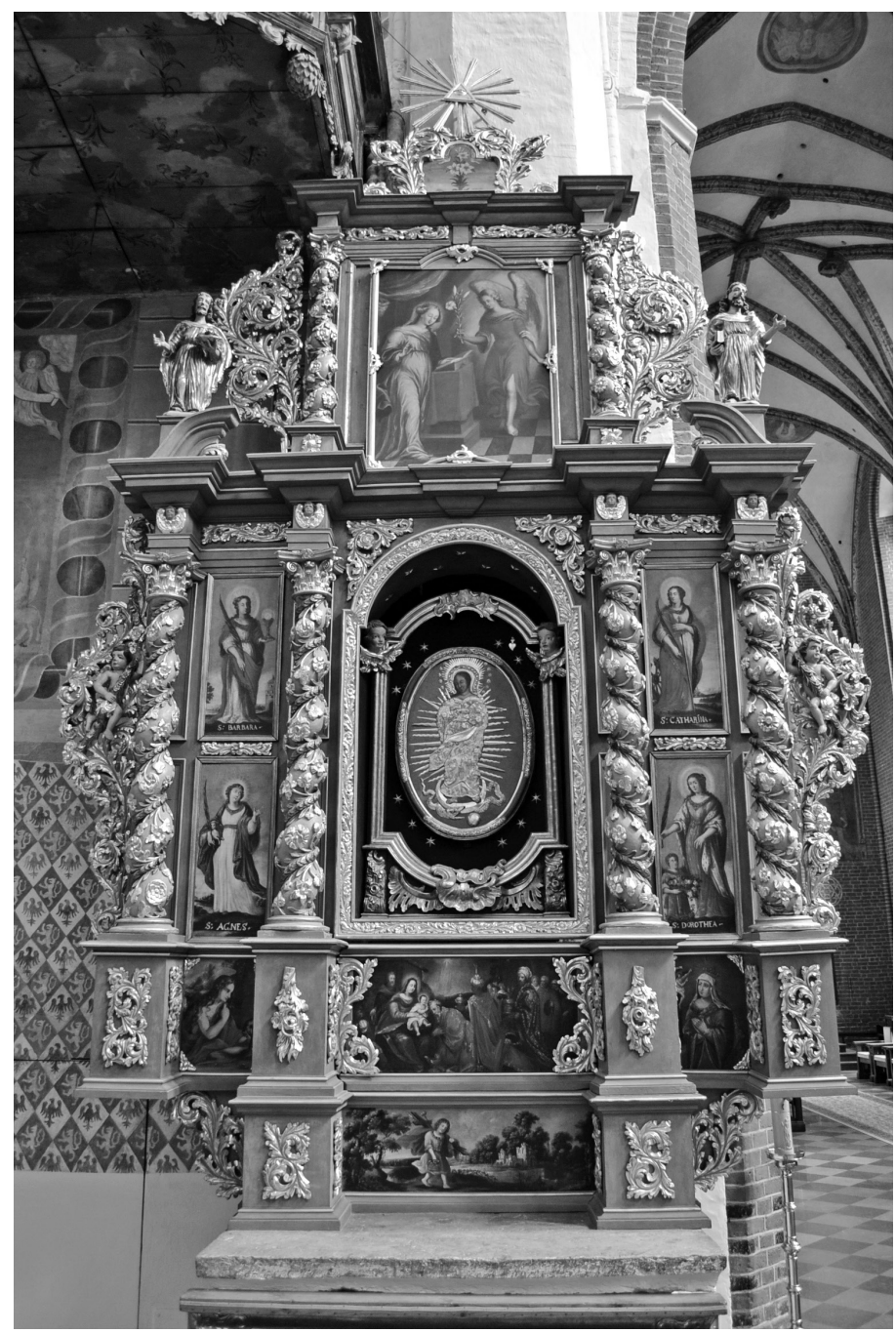

Toruń, katedra

św. Jana Chrzciciela

i św. Jana Ewangelisty.

Retabulum ołtarza

p.w. Niepokalanego

Poczęcia Najświętszej

Maryi Panny.

Widok ogólny od strony frontu, fot. Weronika Kofel, 2016

Powstanie ołtarza pw. Niepokalanego Poczęcia NMP przypada na rok 1690. Ołtarz to przykład struktury z retabulum o konstrukcji w typie $S$, pozornie samonośnej, o układzie konstrukcyjnym dwupoziomowym, zbudowanej z trzech modułów konstrukcyjnych: dwóch modułów złożonych oraz modułu prostego. Na pierwszym poziomie układu konstrukcyjnego występuje moduł prosty i złożony. W skład drugiego poziomu wchodzi wyłącznie moduł złożony. Moduł prosty według podziałów kompozycyjnych występujących od strony lica, odpowiada dolnej części strefy cokołowej retabulum i wykonany został w konstrukcji wieloskrzyniowej o korpusie wczepowym. W konstrukcji tego rodzaju ścinki boczne skrzyni z ścianką dolną i górną połączone zostają przy pomocy złącza wczepowego-skośnego, natomiast połączenie ścianki przedniej skrzyni oraz bocznych z tylną następuje przy pomocy 
Toruń, katedra św. Jana Chrzciciela

i św. Jana Ewangelisty.

Retabulum ołtarza p.w. Niepokalanego Poczęcia

Najświętszej Maryi Panny.

Fragment dokumentacji

pomiarowo rysunkowej

retabulum. Widok frontu,

odwrocia i boku retabulum,

oprac. Weronika Kofel, 2016
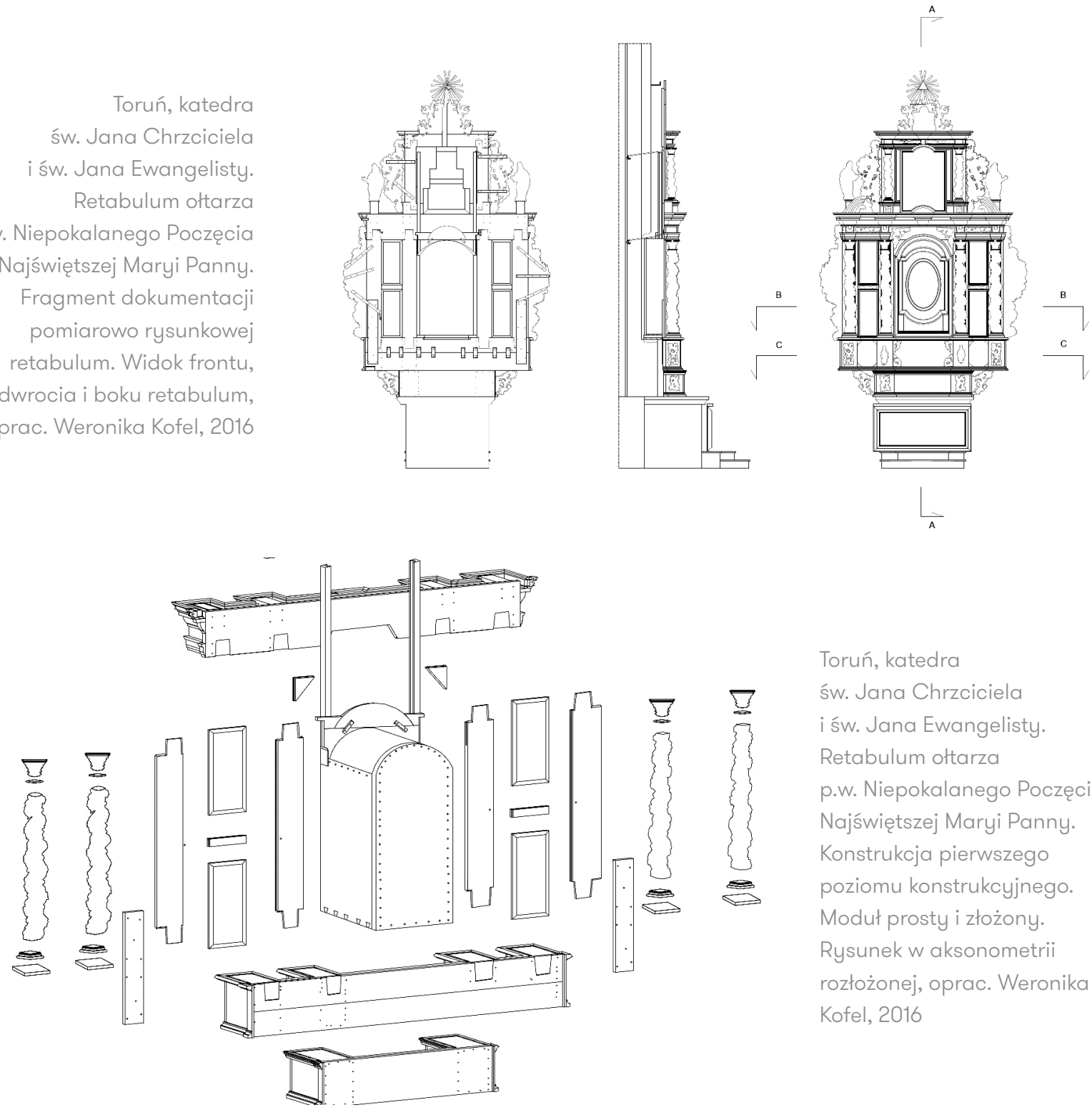

Toruń, katedra

św. Jana Chrzciciela i św. Jana Ewangelisty.

Retabulum ołtarza p.w. Niepokalanego Poczęcia Najświętszej Maryi Panny. Konstrukcja pierwszego poziomu konstrukcyjnego. Moduł prosty i złożony. Rysunek w aksonometrii rozłożonej, oprac. Weronika Kofel, 2016

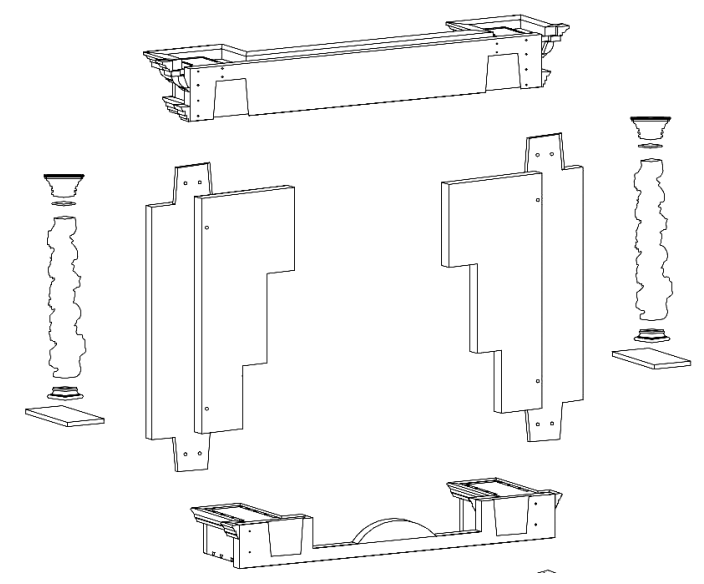

Toruń, katedra św. Jana Chrzciciela i św. Jana Ewangelisty. Retabulum ołtarza p.w. Niepokalanego

Poczęcia Najświętszej Maryi Panny. Konstrukcja pierwszego poziomu konstrukcyjnego. Moduł złożony.

Rysunek w aksonometrii rozłożonej, oprac. Weronika Kofel, 2016 
kołków. Na moduł złożony, który w podziale kompozycyjnym odpowiada pozimowi górnej strefie cokołowej, środkowej i belkowania składają się różnorodne rozwiązania konstrukcyjne. Przestrzenny układ konstrukcyjny w module wzniesiony został w oparciu o rozwiązania konstrukcji wieloskrzyniowej, złożonej z czterech korpusów o konstrukcji wczepowej. Zastosowane w tym miejscu szczegółowe rozwiązania konstrukcyjne, połączenia i złącza stolarskie są analogiczne do tych występujących w module prostym. W przypadku omawianego retabulum warto zwrócić uwagę na sposób rozwiązania ścianek tylnych w konstrukcji wieloskrzyniowej we wskazanym module. W przypadku drewnianej struktury odpowiadającej dolnemu poziomowi strefy cokołowej, ścinka tylna została wykonana z dwóch elementów deskowych, połączonych ze sobą na styk oraz wtórnie przy pomocy metalowych okuć mocowanych na wkręty. Natomiast w strefie belkowania, ściankę tylną stanowi pojedynczy element deskowy. Wydzielona w kompozycji strefa środkowa została wzniesiona przy użyciu konstrukcji ramowo-płycinowej, składającej się z czterech ramiaków pionowych i czterech ramiaków poziomych ( $\mathrm{w}$ tym dwóch ramiaków poziomych-pośrednich). Ramiaki pionowe z poziomymi połączono ze sobą złączem szpungowym ze wzmocnieniem uciosowym. Funkcję ramiaka poziomego spełnia ścinka tylna konstrukcji wieloskrzyniowej, która jest przykładem elementu dwufunkcyjnego. Ramiaki poziome-pośrednie $\mathrm{z}$ ramiakami pionowymi połączono za pomocą złącza wpustowo-wypustowego i gwoździ kutych. Płyciny natomiast umieszczono w ramiakach wykorzystując złącze pełnowpustowe. Szczegółowe rozwiązania konstrukcyjnie, rodzaje połączeń i złącz stolarskich występujące w module złożonym zlokalizowanym w górnym poziome układu konstrukcyjnego, powielą w ogólnym założeniu strukturę konstrukcyjną modułu wcześniejszego. $Z$ tą różnicą, że zupełnie
Toruń, katedra

św. Jana Chrzciciela

i św. Jana Ewangelisty.

Retabulum ołtarza

p.w. Niepokalanego

Poczęcia Najświętszej

Maryi Panny. Fragment

konstrukcji retabulum.

Sposób połączenia

konstrukcji przestrzennych

i płaszczyznowych

w module złożonym,

oprac. Weronika Kofel, 2016
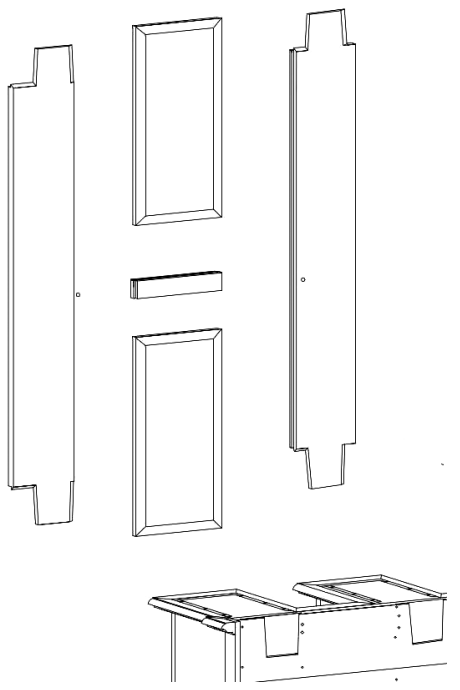
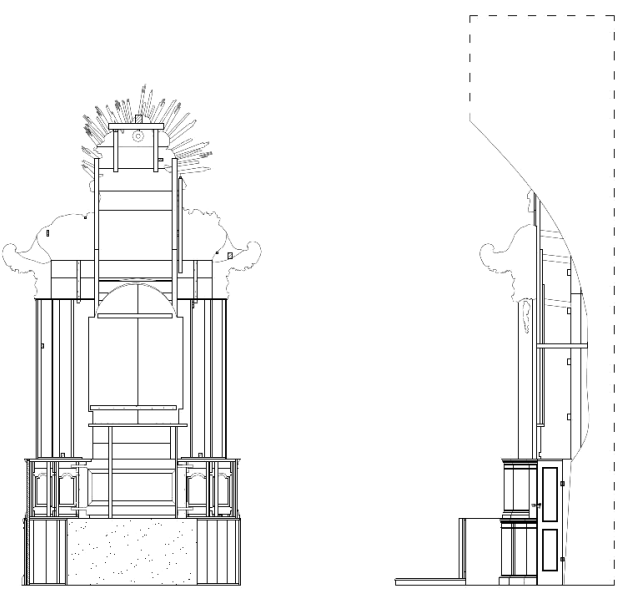

Toruń, kościół pw. św. Jakuba Apostoła. Retabulum ołtarza pw. św. Józefa. Fragment dokumentacji pomiarowo rysunkowej retabulum. Widok frontu, odwrocia i boku retabulum, oprac. Weronika Kofel, 2016 
inaczej zostaje rozwiązana konstrukcja płaszczyznowa. Strefę środkową modułu złożonego zbudowano w konstrukcji ramowej, z ramiaki połączonymi na złącze szpungowe ze wzmocnieniem w postaci gwoździ kutych.

Złożona problematyka konstrukcyjna w szczególności charakterystyczna jest dla retabulów w typie SP, przykładem tego rozwiązania jest ołtarz pw. św. Józefa, którego powstanie datowane jest na lata 1760-1780. Strukturę drewnianą retabulum tworzy konstrukcja pozornie samonośna, o układzie konstrukcyjnym jednopoziomowym, złożona z pięciu modułów konstrukcyjnych- dwóch modułów prostych, dwóch modułów mieszanych łączonych oraz modułu prostego łączonego.

Toruń, kościół pw. św. Jakuba Apostoła.

Retabulum ołtarza pw. św. Józefa. Konstrukcja retabulum z widocznymi dwoma modułami prostymi i modułem mieszanym łączonym.

Rysunek w aksonometrii rozłożonej, oprac. Weronika Kofel, 2016

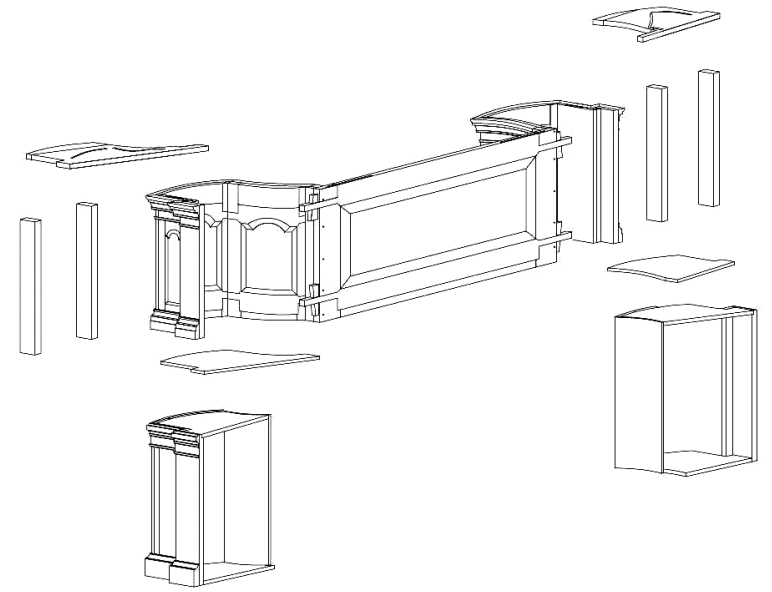

W przypadku wydzielonej w podziale kompozycyjnym strefy cokołowej, jej dolna część skonstruowana została w oparciu o dwa moduły proste. Skrzynie flankujące po bokach stipes i mense, wykonano w konstrukcji niepełnej-stojakowej. Poszczególne ścianki skrzyń wykonano w konstrukcji deskowej i połączono ze sobą przy pomocy złącza na styk kołkowanego. Natomiast ściankę górną z ścinkami bocznymi połączono z wykorzystaniem złącza wręgowego. Górna część strefy cokołowej wzniesiona została w oparciu o założenia modułu mieszanego łączonego. W module mieszanym zestawiono ze sobą na styk kołkowany dwa odmienne układy konstrukcyjne. Zbiór elementów wchodzących w skład układu konstrukcyjnego przestrzennego, tworzy konstrukcje skrzyniowe o korpusach stojakowych-niepełnych. Ścinki boczne skrzyń wykonano w konstrukcji ramowo-płycinowej, w której 


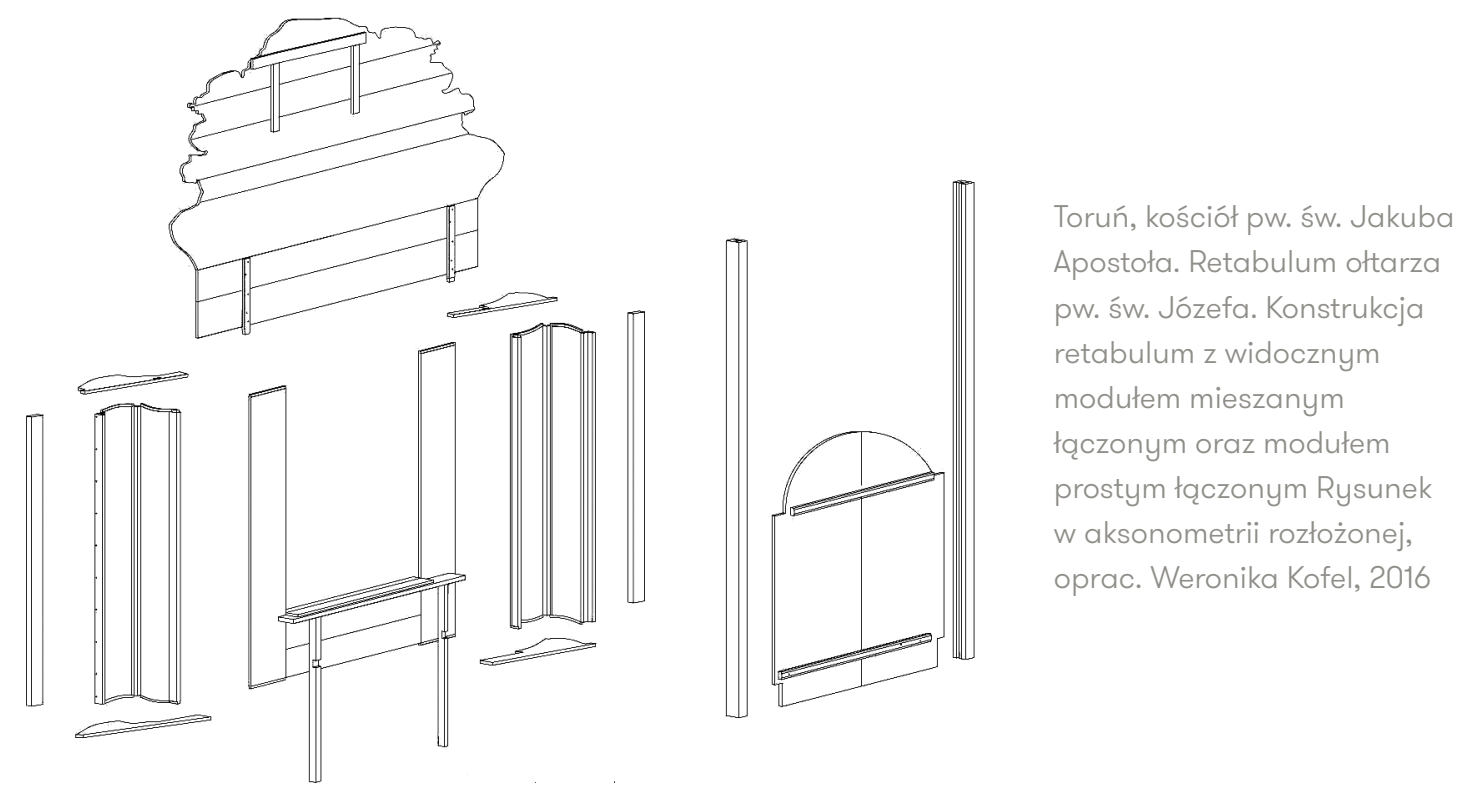

poszczególne ramiaki połączono za pomocą złącza szpungowego z wzmocnieniem uciosowym. Płyciny umieszczono w ramiakach wykorzystując złącze pełno-wpustowe. Ściankę górną i dolną skrzyń połączono z ścinkami bocznymi na styk. Dodatkowo ścinka górna korpusu podtrzymywana jest przez dwa elementy graniakowe, ustawione wewnątrz skrzyni. Układ konstrukcyjny płaszczyznowy w module tworzy konstrukcja ramowo-płycinowa, w której ramiaki połączono poprzez złącze szpungowe, przelotowe $\mathrm{z}$ klinem. Natomiast płycinę umieszczono w ramiakach na sposób pełno-wpustowy. Kolejny moduł mieszany łączony wykorzystany został do wzniesienia, wydzielonej w podziale kompozycyjnym od strony frontu strefy środkowej. Jednakże jego szczegółowa budowa konstrukcyjna jest zupełnie inna. Konstrukcja widocznych od strony frontu form pilastrów, wzniesiona została w oparciu o założenia konstrukcji skrzyniowej niepełnej-mieszanej (o korpusach stojakowo-wieńcowych). Ścianki skrzyń wykonano w konstrukcji deskowej z pojedynczych elementów deskowych i granikowych połączonych ze sobą na styk kołkowany. Na osi wskazanego modułu zlokalizowana została konstrukcja ramowa-niepełna. W której ramiaki pionowe wykonano z pojedynczej deski, natomiast ramiak poziomy-dolny z układu dwóch elementów deskowych. Elementy ramy połączono ze sobą przy pomocy złącza wpustowo-wypustowego. Strefę środkową retabulum zamyka rozbudowane 
zwieńczenie, zbudowane w oparciu o założenia modułu prostego łączonego, a dokładnie konstrukcji deskowej składającej się z siedmiu elementów. Poszczególne poziome elementy deskowe połączono ze sobą za pomocą złącza wpustowo-wypustowego. Dodatkowo układ deskowy w dolnej i górnej części strefy, wzmocniono przy pomocy elementów graniakowych. Trzy moduły łączone połączone zostały pomiędzy sobą za pomocą złącza wpustowo-wypustowego oraz złącza czopowego-przelotowego ${ }^{16}$.

\section{Podsumowanie}

Ołtarze nowożytne jako jeden z elementów wyposażenia przestrzeni sakralnej świątyni, należy uznać za szczególny przykład sprzętów kościelnych. Złożoność tego rodzaju obiektów wynika nie tylko z ich znaczenia w praktyce religijnej, ale również z wielowątkowej problematyki konserwatorskiej, na którą składają się zagadnienia artystyczne, funkcjonalne oraz konstrukcyjne.

Wyróżnione w artykule podstawowe typy konstrukcyjne retabulum opierają się na rozpoznaniu relacji zachodzących pomiędzy poszczególnymi elementami ołtarza oraz zrozumieniu zasad statyki i nośności jego drewnianych struktur. Jednocześnie należy zauważyć, że podstawą dla prawidłowego rozpoznania budowy ołtarza, jest dostęp do jego odwrocia. Zaprezentowana trójetapowa metoda badań konstrukcji retabulów pozwala na faktyczne rozpoznanie drewnianej struktury obiektu. Dzięki przyjętej formie wizualizacji obiektów możliwe jest czytelne ukazanie złożonej problematyki konstrukcyjnej ołtarzy, która może okazać się szczególnie pomocna w trakcie demontażu retabulum czy przy kolejnych etapach prac konserwatorsko-restauratorskich. Wskazana metoda badań retabulów ma jednocześnie na celu upowszechnienie badań konstrukcji i ich standaryzację według opracowanego modelu.

Jak można zauważyć problematyka konstrukcyjna nowożytnych retabulów omówiona na przykładzie ołtarzy toruńskich jest zagadnieniem złożonym. W analizowanym zespole obiektów, można wyróżnić retabula o konstrukcji w typie S, S+ oraz SP. Znaczna różnorodność rozwiązań w szczególności charakterystyczna jest dla obiektów w typie SP. Wiąże się to z zastosowaniem do ich budowy modułów mieszanych, których szczegółowa budowa konstrukcyjna jest bardzo zróżnicowana, jak pokazuje to analiza retabulum ołtarza pw. św. Józefa. Dodatkowo w przypadku retabulów w typie SP ich zasadnicza konstrukcja wynika z wykorzystania do ich wzniesienia samodzielnych bądź niesamodzielnych modułów konstrukcyjnych (modułów łączonych). W przypadku konstrukcji retabulów w typie S, składających się z modułu złożonego, różnorakość rozwiązań konstrukcyjnych skupia się na rodzaju zastosowanego złącza stolarskiego do połączenia odmiennych konstrukcyjnie układów (przestrzennych i płaszczyznowych). W modułach złożonych w retabulum ołtarza pw. Niepokalanego Poczęcia NMP zastosowano

16 Moduły mieszane łączone połączono przy użyciu złącza wpustowo-wpustowego, natomiast moduł mieszany łączony z modułem prostym łączonym przy pomocy złącza czopowego przelotowego. 
złącze szpungowe oraz złącze szpungowe ze wzmocnieniem uciosowym. Złącza tego rodzaju występują najczęściej w tego typu rozwiązaniach konstrukcyjnych.

Przedstawiona analiza ołtarzy pokazuje, że badania zorientowane na problematykę konstrukcyjną pozwalają zrozumieć budowę drewnianej struktury retabulów. Umożliwiają zidentyfikowanie poszczególnych elementów konstrukcyjnych, ich formy i połączeń. Badania konstrukcji ołtarzy, w tym śladów pierwotnej obróbki drewna mogą dostarczać niezbędnych informacji do dokonania rozwarstwienia chronologicznego obiektów. Warto podkreślić, że rozróżnienie pierwotnych i wtórnych elementów konstrukcyjnych i ich wartościowanie, może okazać się pomocne w procesie konserwacji i restauracji. Identyfikując pierwotną formę konstrukcji i rozumiejąc jej budowę, staje się ona obok elementów dekoracyjnych detalem, który w trakcie prac konserwatorsko-restauratorskich należy niezwłocznie zachować. Doceniając wartość konstrukcji podczas jakichkolwiek prac naprawczych powinno się dążyć do zachowania jej integralności. Rozpoznanie problematyki konstrukcyjnej retabulów może również przyczynić się do uzupełnienia informacji o ołtarzach pozyskiwanych ze źródeł pisanych czy ikonograficznych oraz stanowić ważne uzupełnienie dla wiedzy z zakresu historii technik budowlanych.

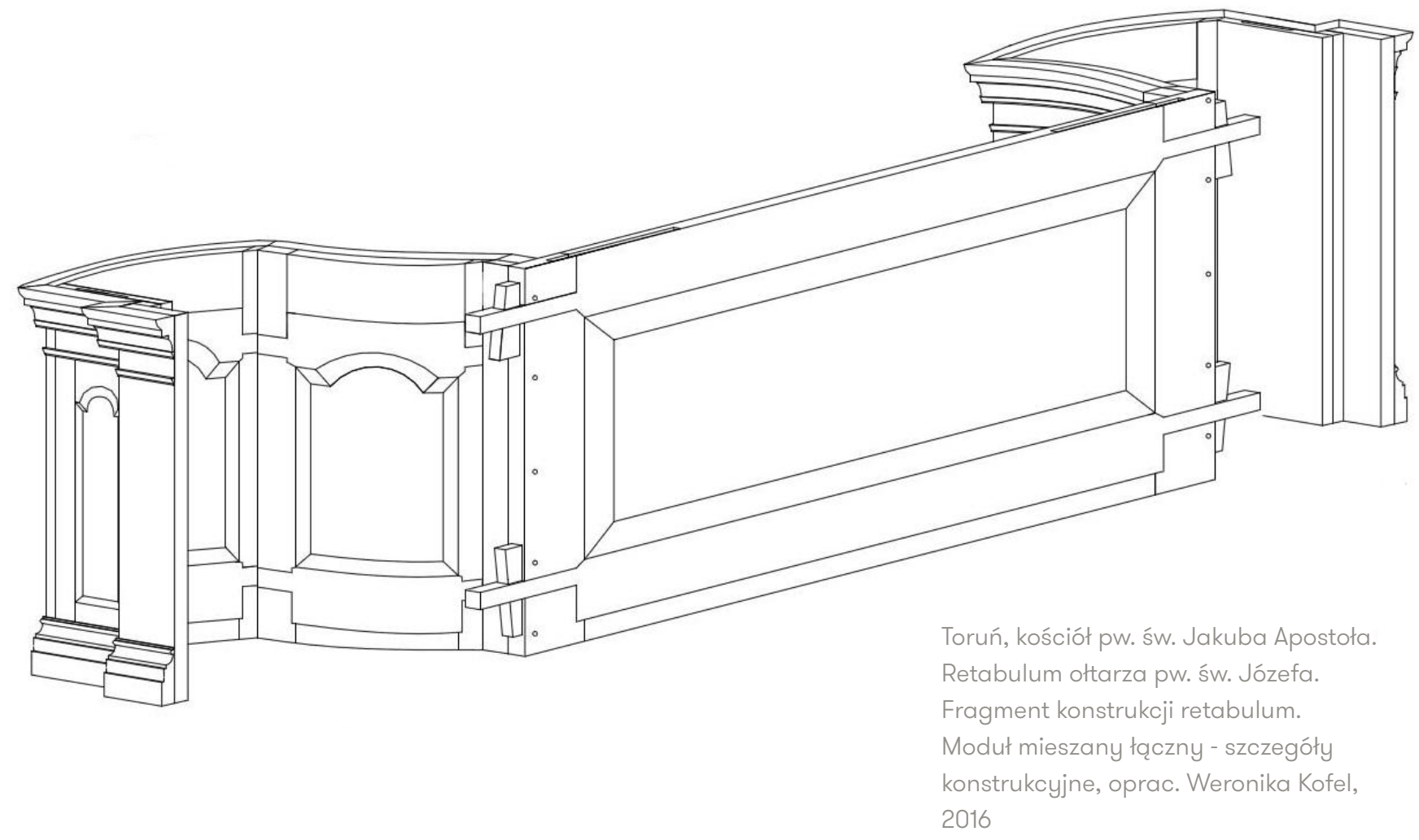




\section{Bibliografia:}

- BAZYLIKA KATEDRALNA 2003 - Bazylika katedralna św. Janów w Toruniu, red. M. Biskup, Toruń 2003;

- BŁAŻEJEWSKA/KLUCZWAJD/MANSFELD/PILECKA/TYLICKI 2009 - Anna Błażejewska, Katarzyna Kluczwajd, Bogusław Mansfeld, Elżbieta Pilecka, Jacek Tylicki, Dzieje Sztuki Torunia, Toruń 2009;

- DOMASŁOWSKI 1992 - Jerzy Domasłowski, Kościół akademicki św. Ducha w Toruniu. Dzieje, architektura, wyposażenie wnętrza, „Rocznik Toruński”, t. 21, 1992, s. 173-203;

- DOMASŁOWSKI 2007 - Jerzy Domasłowski, Kościół św. Piotra i Pawła i klasztor Franciszkanów (dawniej Reformatów) na Podgórzu w Toronu, Toruń 2007;

- DOMASŁOWSKI/JARZEWICZ 1998 - Jerzy Domasłwoski, Jarosław Jarzewicz, Kościół Najświętszej Marii Panny w Toruniu, Toruń 1998;

- DZIEJE I SKARBY 2003 - Dzieje i skarby kościoła Świętojańskiego w Toruniu. Materiały z konferencji przygotowanej przez Toruński Oddział Stowarzyszenia Historyków Sztuki przy współpr. Instytutu Zabytkoznawstwa i Konserwatorstwa Uniwersytetu Mikołaja Kopernika 22-23 III 2002, red. K. Kluczwajd, M. Woźniak, Toruń 2003;

- DZIEJE I SKARBY 2005 - Dzieje i skarby kościoła Mariackiego w Toruniu. Materiały z konferencji przygotowanej przez Toruński Oddział Stowarzyszenia Historyków Sztuki przy współpr. Instytutu Zabytkoznawstwa i Konserwatorstwa Uniwersytetu Mikołaja Kopernika (Toruń 14-16 kwietnia 2005), red. K. Kluczwajd, Toruń 2005;

- DZIEJE I SKARBY 2007 - Dzieje i skarby kościołów Torunia Podgórza, red. K. Kluczwajd, Toruń 2007;

- DZIEJE I SKARBY 2010 - Dzieje i skarby kościoła Świętojakubskiego w Toruniu . Materiały z IV Sesji Naukowej Toruńskiego Oddziału Stowarzyszenia Historyków Sztuki, z cyklu Dzieje i skarby kościołów toruńskich, zrealizowanej przy współpracy Biblioteki Uniwersyteckiej UMK w Toruniu, 26-28 października 2009 roku, red. K Kluczwajd, Toruń 2010;

- GOŁAWSKA 1968 - Jolanta Goławska, Snycerska Toruńska w okresie baroku, „Teka Komisji Historii Sztuki”, t. 4, 1968, s. 157-224;

- HEISE 1889 - Johannes Heise, Die Bau-und Kunstdenkmäler Provinz Westpreussen, H.6-7, Kreis Thorn, Danzing 1889;

- JAKUBOWSKA 1965 - Bogna Jakubowska, Snycerka toruńska XVIII wieku, „Teka Komisji Historii Sztuki”, t. 3, s. 1965 , s. 155-220;

- KOFEL 2016 a - Weronika Kofel, Konstrukcje toruńskich nastaw ołtarzowych w XVII i XVIII w., Toruń 2016 (praca niepublikowana);

- KOFEL 2016 b - Weronika Kofel, Katalog ottarzy toruńskich z XVII i XVIII w., Toruń 2016 (praca niepublikowana);

- KRANTZ-DOMASŁOWSKA/DOMASŁOWSKI 2001 - Lilianna Krantz-Domasłwoska, Jerzy Domasłowski, Kościół św. Jakuba w Toruniu, Toruń 2001;

- LIPSKA/ RDESIŃSKA 2010 - Dąbrówka Lipska, Maria Rdesińska, Wyposażenie kościoła pw. św. Jakuba w Toruniu w XVII i XVIII wieku. Historia i zmiany w koncepcji przestrzeni liturgicznej, [w:] Dzieje i skarby kościoła Świętojakubskiego w Toruniu. Materiały z IV Sesji Naukowej Toruńskiego Oddziału Stowarzyszenia Historyków Sztuki, z cyklu Dzieje i skarby kościołów toruńskich, zrealizowanej przy współpracy Biblioteki Uniwersyteckiej UMK w Toruniu, 26-28 października 2009 roku, red. K Kluczwajd, Toruń 2010, s. 289-310;

- ŁYCZAK 2015 - Bartłomiej Łyczak, Toruński cech rzeźbiarski i snycerka na obszarze jego oddziaływania w latach 1695-1793, Toruń 2015 (praca niepublikowana);

- MACHALA 2007 - Machala Peter, Ołtarz główny w kościele pw. św. Piotra i Pawła na Podgórzu, [w:] Dzieje i skarby kościołów Torunia Podgórza, red. K. Kluczwajd, Toruń 2007, s. 117-146;

- SZMIT-NAUD 1996 - Elżbieta Szmit-Naud, Dokumentacja konserwatorska ołtarza Matko Boskiej Niepokalanej w katedrze śś. Jana Chrzciciela i Jana Apostoła w Toruniu, Toruń 1996 (WKZ w Toruniu). 
- SZMIT-NAUD 2010 - Elżbieta Szmit-Naud Transformacja ołtarzy na podstawie historii materialnej kilku zabytków z katedry św. św. Jana Chrzciciela i Jana Ewangelisty w Toruniu. Zmiany formy, ikonografii i wezwań, [w:] Zabytkowa stolarka we wnętrzach sakralnych i jej problematyka konserwatorska, red. Janusz Krawczyk, Toruń 2010, s. 153-165.

- TRYBUZEWSKI 2006 - Piotr Trybuszewski, Nastawa ołtarza głównego z kościoła Świętego Jakuba w Toruniu. Budowa i problematyka konserwatorska, „Rocznik Muzeum Okręgowego w Toruniu”, t. 15, 2006, s. 9-44;

- TRYBUSZEWSKI 2010 - Piotr Trybuszewski, Problematyka konstrukcyjna i konserwatorska ołtarza głównego kościoła św. Jakuba w Toruniu, [w:] Zabytkowa stolarka we wnętrzach sakralnych i jej problematyka konserwatorska, red. J. Krawczyk, Toruń 2010, s. 167-180;

- WARDZYŃSKA 2010 - Katarzyna Wardzyńska, Ottarz główny i łuk tęczowy kościoła Benedyktynek pw. św. Jakuba w Toruniu. Nieznane dzieła Johanna Antona Langenhana Starszego i Jerzego Judy Tadeusza Dąbrowicza, [w:] Dzieje i skarby kościoła Świętojakubskiego w Toruniu . Materiały z IV Sesji Naukowej Toruńskiego Oddziału Stowarzyszenia Historyków Sztuki, z cyklu Dzieje i skarby kościołów toruńskich, zrealizowanej przy wspólpracy Biblioteki Uniwersyteckiej UMK w Toruniu, 26-28 października 2009 roku, red. K Kluczwajd, Toruń 2010, s. 311-345;

- WERNICKE - Julius Wernicke, Die Kirchen der Stadt Thorn und ihres Gebietes. Eine Historische Darstellung des Ursprungs, Fortgangs und Schicksale dieser Kirchen bis zur Gegenwart, rks. Archiwum Państwowe w Toruniu, Kat II, X-25, s. 751-846;

- WERNICKE 1832 - Julius Wernicke, Topographisch-historisch-statistische Beschreibung der Stadt Thorn und ihres Gebietes: die Vorzeit und Gegenwart umfassend, Thorn 1832;

- WERNICKE 1846 - Julius Wernicke, Wegweiser durch Thorn und seine Umgebungen, Thorn 1846. 


\section{The Issue of the Structure of the Modern-Period Retabula, Illustrated with an Example of Selected Altars in Toruń-based Churches}

issues related to the modern-period retabula, illustrated with an example of selected Torun-based altars in the Cathedral of St. John the Baptist and St. John the Evangelist, the Church of St. James the Greater, and the Church of the Assumption of the BVM. The article has been divided into four sections. The first one describes the research method applied to study the structure of modern-period retabula, which is a three-stage process including: the inventory of the building, aimed at drafting a measurement and drawing documentation, the production ofexploded-view drawings that contain details of structural solutions, and the description of the construction of the building, which also takes a three-stage form. In the next section, basic terms related to the construction of retabula have been presented, with distinguished structural types of retabula, divided into three catego- 
ries: type S, S+ and SP. The issue of the dead load of wooden constructions and its distribution was also discussed, and the analysis of such properties rendered it possible to distinguish load-bearing, self-supporting and quasi-self-supporting structures among modern-period retabula. In addition, the issue of the structural layout of retabula and their modular design was discussed, with a description of the following modular units: simple, complex, mixed and combined modules. In the next part of the article, the current status of the research devoted to Torun-based altars was presented, including a review of the most prominent publications on historical, stylistic and maintenance matters, with a particular focus on theworks by Piotr Trybuszewski and Peter Machala, related to structural issues of retabula. The final section of the article was devoted to the analysis of the structure of selected retabulain Torun-based churches. A detailed structural study was conducted on the Altar of the Immaculate Conception of the Blessed Virgin Mary within the Cathedral of St. John the Baptist and St. John the Evangelist, and the Altar of St. Joseph in the Church of St. James the Greater. In this part, individual structural solutions were described, together with their construction and design types of their retabula. Next, the number of structural modules and their types were discussed, together with a presentation of a detailed design and structure of the modules, including the applied types of woodworking joints and connections. 